\title{
WORKSHOP PENINGKATAN KEMAMPUAN MERANCANG KEGIATAN LABORATORIUM BERORENTASI PADA PENDEKATAN SAINTIFIK BAGI GURU FISIKA SIDOARJO
}

\section{WORKSHOP TO IMPROVE CAPABILITY OF LABORATORY ACTIVITY DESIGN-ORIENTED ON SCIENTIFIC APPROACH FOR PHYSICS TEACHERS IN SIDOARJO}

\author{
Setyo Admoko ${ }^{1}$ dan Supriyono ${ }^{2}$ \\ 1,2Jurusan Fisika, Fakultas Matematika dan IPA, Universitas Negeri Surabaya \\ Jl. Ketintang, Surabaya 60231, Indonesia
}

e-mail: asetyoadmoko@unesa.ac.id dan bsupriyono@unesa.ac.id

\begin{abstract}
Abstrak
Kemampuan guru dalam merancang kegiatan laboratorium inkuiri masih rendah, sehingga mereka tidak melaksanakan kegiatan itu dalam pembelajaran Fisika. Kegiatan workshop pelatihan ini bertujuan untuk mengembangkan kemampuan merancang dan melaksanakan kegiatan laboratorium Fisika berbasis inkuiri bagi Guru Fisika MGMP Sidoarjo. Kegiatan ini dilakukan dengan melatihkan tujuh aspek yang diduga dapat mendukung pengembangan kemampuan merancang kegiatan laboratorium tersebut, yaitu (1) menentukan tujuan kegiatan laboratorium; (2) menentukan jenis percobaan yang sesuai dengan tujuan; (3) menentukan alat dan bahan laboratorium sesuai dengan spesifikasi yang dibutuhkan; (4) menentukan rangkaian percobaan dan menggambarkan diagramnya;(5) merencanakan sendiri prosedur percobaan dan melaksanakannya; (6) menyusun lembar kerja siswa berbasis inkuiri; dan (7) merancang evaluasi kegiatan laboratorium. Aspek-aspek kemampuan tersebut dikembangkan melalui tiga tahap pelatihan, yaitu penyelenggaraan contoh (atau pemodelan) kegiatan laboratorium Fisika berbasis inkuiri, perancangan kegiatan laboratorium inkuiri, dan implementasi hasil rancangan dalam simulasi pembelajaran. Keberhasilan pengembangan kemampuan tersebut dievaluasi menggunakan Lembar Kerja Pelatihan dan Angket Respon peserta pelatihan terhadap pelaksanaan pelatihan. Hasil kemampuan merancang kegiatan laboratorium bagi guru-guru Fisika MGMP Sidoarjo mendapatkan nilai rerata skor 3,49 yang masuk dalam kategori sangat baik. Respon guru-guru yang memberi tanggapan positif terhadap kegiatan pelatihan merancang kegiatan laboratorium sebanyak $91 \%$., hal ini mennunjukkan bahwa kegiatan pelatihan yang dilaksakan sesuai keinginan dan kebutuhan guru fisika peserta pelatihan.
\end{abstract}

Kata Kunci: kegiatan laboratorium, guru fisika, pendekatan saintifik, pelatihan

\begin{abstract}
Teachers capability on inquiry-based laboratory activity design was still low, so they didn't do that activity in Physics learning. This workshop aimed for developing capability of designing and conducting inquiry-based laboratory for Physics MGMP Teachers in Sidoarjo.This training activity intended to train seven aspects which are expected to support developed capability of laboratory activity design, that were (1) determined laboratory activity's purpose;(2) determined the type of experiment that suitable for the
\end{abstract}

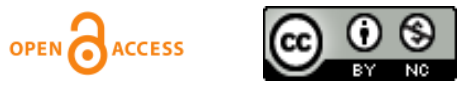


purpose; (3) decided tools and materials suitable with laboratory specification needed; (4) decided the research series and drew the diagram; (5) planned and conducted experiment procedure; (6) arranged inquiry-based students' worksheet; and (7) designed laboratory activity assessment. Those aspects developed by three training steps, they were modeling of inquiry-based Physics Laboratory, designed inquiry-based laboratory activities, and implemented result design of learning simulation.The succeed of developed those capability was evaluated using Training Worksheet and Responses Questionnaire of training participant. The capability result of design laboratory activity for Physics MGMP teachers in Sidoarjo got average score 3,49 which was in good criteria. The teacher's responses gave a positive reaction toward laboratory design training activity was $91 \%$. This showed that the workshop program was held based on Physics teachers participants' willingness and need.

Keywords: laboratory activity, physics teachers, scientific approach, workshop

Copyright @ 2016 Jurusan Fisik FMIPA Universitas Negeri Surabaya

\section{PENDAHULUAN}

Pembelajaran yang dilaksanakan para guru cenderung untuk mengajar seperti guru diajar ketika kuliah. Apabila guru saat kuliah diajar menggunakan metode ceramah, maka saat menjadi guru juga lebih menyukai mengajar dengan cara ceramah, walaupun pembelajaran tersebut tidak cocok untuk siswa-siswanya. Banyak guru tidak dapat memisahkan ilmu fisika yang telah dipelajari dengan cara ilmu fisika tersebut diajarkan kepada siswa [1], Guru harus diberi kesempatan untuk memeriksa hakekat materi subjek, untuk memahami tidak hanya mengenai apa yang diketahui, tetapi bagaimana fakta-fakta darimana pengetahuan itu diperoleh secara rasional. Pemahaman konseptual fisika dasar dan kemampuan berargumen ilmiah akan memberikan suatu fondasi yang kuat untuk mengajar efektif daripada belajar mengenai materi yang tinggi tetapi dangkal [1].

Pembelajaran fisika pada umumya dilaksanakan dengan metode ceramah baik oleh guru secara langsung ataupun meminta siswa untuk membaca materi tertentu, menyusun makalah secara berkelompok, kemudian menyajikannya di depan kelas. Kemudian dilakukan diskusi dan tanya jawab mengenai isi makalah tersebut. Dalam pelaksanaan diskusi dan tanya jawab, siswa mengajukan pertanyaan mengenai hal-hal yang dianggap belum jelas kepada kelompok penyaji. Kelompok penyaji secara bergiliran menjawab pertanyaan-pertanyaan tersebut. Apabila kelompok penyaji tidak dapat memberikan jawaban, maka moderator, yaitu salah seorang dari kelompok penyaji, melemparkan pertanyaan tersebut kepada guru. Selanjutnya guru memberikan jawaban langsung kepada siswa. Selama pembelajaran, sangat minim kegiatan laboratorium ataupun kegiatan lapangan. Perkuliahan seperti ini mempunyai kelemahan antara lain:

1. Pengetahuan konsep/prinsip atau teori diperoleh siswa dari hasil membaca buku atau informasi dari guru, bukan merupakan hasil penemuan dari proses sains yang dilakukan mahasiswa. Akibatnya pengetahuan yang diperoleh hanya sebatas mengetahui, bukan memahami. Informasi yang diperoleh dengan cara seperti ini akan lebih cepat terlupakan; dan

2. Siswa lebih cenderung mempelajari topik yang menjadi bagian tugas presentasinya, sedangkan topik-topik lainnya dipelajari sekedarnya saja. Menurut siswa cara pembelajaran seperti yang mereka alami tidak menjadikan mereka lebih memahami materi. 
Sains merupakan kumpulan pengetahuan tentang obyek atau gejala alam yang telah diuji kebenarannya [2] Sains mencakup dua aspek yaitu Sains sebagai proses, yang dikenal dengan metode ilmiah dan Sains sebagai produk yang dikenal dengan body of knowledge. Sains juga memiliki nilai-nilai ilmiah atau value of science yang melekat pada pengetahuan ilmiah [3]. Sains sebagai proses berawal dari observasi terhadap fenomena alam dengan cara kerja sebagaimana yang dilakukan oleh para saintis. Oleh karena itu pembelajaran Fisika sebaiknya dimulai dari observasi terhadap fenomena alam. Melalui proses ilmiah dapat dikembangkan sikap ilmiah siswa. Sikap ilmiah tersebut mencakup sikap ingin tahu, menghargai pembuktian, berpikir kritis, kreatif, berbicara berdasarkan kepada bukti-bukti konkrit atau data, dan peduli terhadap lingkungan. Melalui proses IPA dapat dikembangkan keterampilan mengobservasi, menjelaskan, berpikir, memecahkan masalah, dan membuat keputusan [4]. Hal ini bersesuaian dengan maksud pembelajaran fisika yaitu untuk mendidik siswa agar mampu mengembangkan observasi dan eksperimentasi serta berpikir taat asas melalui: mengamati, memahami, dan memanfaatkan gejala-gejala alam yang melibatkan zat (materi) dan energi $[5,6]$.

Ada dugaan bahwa kemampuan guru dalam merancang kegiatan laboratorium inkuiri masih rendah. Dugaan itu didukung hasil penelitian Balitbang Depdiknas [7] yang menunjukkan bahwa sekitar $51 \%$ guru IPA SMP dan sekitar $43 \%$ guru fisika SMA di Indonesia tidak dapat menggunakan alat-alat laboratorium yang tersedia di sekolahnya, akibatnya, tingkat pemanfaatan alat-alat itu dalam pembelajaran cenderung rendah [8].

Selain itu, studi kebijakan Ditdikmenum (1994) menemukan bahwa penguasaan keterampilan proses guru rendah. Hasil studi tersebut menunjukkan bahwa keterampilan proses terpadu seperti mengidentifikasi variabel kontrol, menganalisis eksperimen, dan menyusun rancangan eksperimen terasa asing bagi hampir seluruh siswa maupun guru.

Keberadaan dan kondisi Laboratorium Fisika yang ada di Kabupaten Sidoarjo [9] tercatat 13 SMA Negeri yang memiliki laboratorium ada 8 dan yang berada dalam kondisi baik layak digunakan ada 4 laboratorium. Sementara itu SMA Swasta ada 49 tercatat yang memiliki laboratorium ada 13 dan yang berada dalam kondisi baik layak digunakan ada 7 laboratorium. Berdasarkan data tersebut bila kita gabung antara sekolah negeri dan swasta maka terdapat 62 SMA yang memiliki 21 laboratoium dan hanya ada 11 laboratorium yang dapat digunakan, atau bila dinyatakan dalam persentase sekolah yang memiliki Laboratorium Fisika dan layak digunakan di Kabupaten Sidoarjo hanya ada $18 \%$ dari semua SMA yang ada.

Bagaimana guru akan menyelenggarakan kegiatan laboratorium inkuiri bila guru tidak memiliki sarana prasarana yang menunjang kegiatan tersebut dan gurubelum menguasai keterampilan yang diperlukannya. Sebaliknya, bila guru memiliki kemampuan merancang kegiatan Laboratorium maka guru yang memiliki laboratorium akan termotivasi melaksanakan eksperimen, sedangkan guru yang tidak memiliki alat-alat laboratorium dapat melaksanakan kegiatan eksperimen menggunakan Laboratorium Virtual.

Ada dua faktor utama yang dapat mempengaruhi guru untuk mengembangkan kegiatan laboratorium inkuiri, yaitu faktor kemampuan dan kemauan. Oleh karena itu, dalam rangka meningkatkan mutu pendidikan fisika paling tidak diperlukan dua hal seperti 
berikut. Pertama, peningkatan mutu guru, terutama dalam hal berkaitan dengan peningkatan kemampuan merancang dan menyelenggarakan kegiatan laboratorium berbasis inkuiri. Kedua, penciptaan kondisi yang mampu meningkatkan dan menjaga motivasi guru agar selalu mengupayakan pembelajaran Fisika yang bermutu. Bertolak dari dua hal tersebut, pelatihan ini difokuskan pada masalah peningkatan mutu guru pengajar Fisika anggota MGMP Fisika Kabupaten Sidoarjo, dengan tujuan untuk mengembangkan kemampuan guru dalam merancang kegiatan laboratorium inkuiri untuk mata kuliah Fisika. Upaya ini penting untuk dilakukan, karena salah satu faktor penentu keberhasilan kegiatan laboratorium adalah guru [10], dan hasil pelatihan diharapkan meningkatkan kemampuan guru dalam merancang dan melaksanakan kegiatan laboratorium Fisika, selanjutnya juga diharapkan berpengaruh positif terhadap frekuensi penggunaan laboratorium Fisika.

Berdasarkan uraian latarbelakang di atas dirumuskan permasalahan sebagai berikut:

1. Bagaimana kemampuan merancang kegiatan laboratorium untuk guru anggota MGMP Fisika Kabupaten Sidoarjo setelah mengikuti kegiatan pelatihan?

2. Bagaimanakah respon peserta pelatihan terhadap kegiatan pelatihan dalam merancang dan melaksanankan kegiatan laboratorium yang telah mereka ikuti?

\section{METODE PENELITIAN}

\section{Metode Penyelesaian Masalah}

Kegiatan pelatihan ini bertujuan melatihkan tujuh aspek yang diduga dapat mendukung pengembangan kemampuan merancang kegiatan laboratorium tersebut, yaitu (1) menentukan tujuan kegiatan laboratorium; (2) menentukan jenis percobaan yang sesuai dengan tujuan; (3) menentukan alat dan bahan laboratorium sesuai dengan spesifikasi yang dibutuhkan; (4) menentukan rangkaian percobaan dan menggambarkan diagramnya; (5) merencana- kan sendiri prosedur percobaan dan melaksanakannya; menyusun lembar kerja siswa berbasis inkuiri; dan (7) merancang evaluasi kegiatan laboratorium.

Metode pelaksanaan pelatihan dalam meningkatkan aspek-aspek kemampuan tersebut dikembangkan melalui tiga tahap pelatihan, yaitu penyelenggaraan contoh (atau pemodelan) kegiatan laboratorium Fisika berbasis inkuiri, perancangan kegiatan laboratorium inkuiri, dan implementasi hasil rancangan dalam simulasi pembelajaran. Pada pelaksanaan kegiatan dilakukan monitoring oleh kedua belah pihak yang terkait dan pada akhir kegiatan dilakukan evaluasi terhadap pelaksanaan kegiatan maupun hasil pelatihan.

\section{Parameter Keberhasilan Program}

Program ini dianggap berhasil apabila tim berhasil melaksanakan pelatihan Merancang Kegiatan Laboratorium Berorentasi pada Pendekatan Saintifik bagi Guru Anggota MGMP Fisika Kabupaten Sidoarjo dan Model Rancangan Kegiatan Labortorium yang dibuat oleh Guru Fisika.

\section{Rencana Pengembangan Keberlanjutan Program}

Untuk menjaga keberlanjutan program, dalam jangka panjang akan dikembangkan program pelatihan lebih lanjut yang melibatkan peserta yang lebih banyak dan diharapkan didanai Dinas Pendidikan Kabupaten Sidoarjo secara mandiri.

\section{Persiapan Pelaksanaan Pelatihan}

Persiapan pelaksanaan pelatihan yang dilakukan untuk memperlancar jalannya kegiatan pelatihan yaitu mempersiapkan segala keperluan yang dibutuhkan diantaranya: 
1. Workshop mempersiapkan referensi, piranti kegiatan hardware dan software. Yang bertujuan memperoleh bahan/ referensi, hardware dan software terkait Pelatihan Merancang Kegiatan Laboratorium Fisika bagi Guru Sidoarjo.

2. Menyusun materi pelatihan terkait dengan merancang eksperimen fisika berorientasi pendekatan saintifik.

3. Menyusun instrumen yang diperlukan untuk workshop pelatihan, instrumen desain eksperimen fisika berdasarkan empat pertanyaan ("four questions strategy").

4. Menyusun contoh lembar kerja desain eksperimen berorientasi pendekatan saintifik.

5. Melakukan simulasi internal yang bertujuan untuk melakukan kegiatan simulasi sebelum pelaksanaan workshop pelatihan supaya lebih termonitor kebutuhannya sebelum pelaksanaan workshop pelatihan.

6. Mempersiapkan perangkat pelatihan secara lengkap dan pembagian tugas selama pelatihan.

\section{Hasil Persiapan Pelatihan}

1. Modul "Pelatihan Merancang Kegiatan Laboratorium Berorentasi pada Pendekatan Saintifik bagi Guru Fisika Sidoarjo".

2. Lembar kerja desain dan pelaksanaan eksperimen Fisika.

3. Instrumen beserta rubrik penilaian keterampian Merancang Kegiatan Laboratorium.

4. Angket respon peserta terhadap pelaksanaan pelatihan.

\section{Pelaksanaan Kegiatan Pelatihan}

Berdasarkan hasil koordinasi dengan Kepala Dinas Sidoarjo pelatihan telah kami laksanakan pada hari dan tanggal: Rabu, 2 September 2015 sampai dengan
Jum'at, 4 September 2015 di SMA Negeri 1 Sidoarjo, dan diikuti oleh 34 peserta yang merupakan guru Fisika SMA dan MA Kabupaten Sidoarjo.

Dari pelaksanaan kegiatan "Pelatihan Merancang Kegiatan Laboratorium erorentasi pada Pendekatan Saintifik bagi Guru Fisika Sidoarjo" telah diperoleh data kemampuan guru dalam mendesain dan melaksanakan eksperimen melalui pengisian Lembar kerja desain dan pelaksanaan eksperimen Fisika.

\section{HASIL PENELITIAN DAN DISKUSI}

\section{Kegiatan Penyajian Materi}

Pelaksanaan kegiatan penyajian materi yang telah dilaksanakan bertujuan untuk memberikan pemahaman peserta tentang pengembangan kompetensi kemampuan guru Fisika Kabupaten Sidoarjo dalam merancang dan melaksanankan kegiatan laboratorium. Secara umum kegiatan penyajian materi berlangsung sangat baik. Peserta dengan antusias dan bersungguh-sungguh mengikuti sesi demi sesi sajian materi pelatihan yang disajikan oleh nara sumber. Demikian juga kegiatan diskusi berlangsung sangat baik. Respon peserta maupun tanggapan dari nara sumber berlangsung baik. Banyaknya pertanyaan yang muncul dari peserta menunjukkan adanya respon positif dari peserta terhadap materi pelatihan, disamping juga menunjukkan bahwa banyak hal yang masih perlu diketahui terkait dengan keterampilan merancang dan melaksanakan kegiatan laboratorium.

Dari kegiatan yang telah dilakukan dapat direkam bahwa diskusi yang terjadi mengindikasikan bahwa pengetahuan awal peserta tentang merancang dan melaksanakan kegiatan relatif masih kurang. Akan tetapi setelah diberikan pelatihan, tingkat pemahaman peserta pelatihan menunjukkan hasil yang baik. Pernyataan ini diperkuat 
dengan hasil angket respon peserta pelatihan yang ditunjukan pada Tabel 2 .

Evaluasi Kinerja Desain dan Melakukan

\section{Eksperimen}

Penilaian kemampuan guru Fisika Kabupaten Sidoarjo dalam merancang dan melaksanankan kegiatan laboratorium dilakukan selama kegiatan pelatihan berlangsung. Penilaian dilakukan dengan penilaian kinerja. Jenis-jenis keterampilan dan kemampuan yang dinilai mencakup 16 aspek kinerja.

Berdasarkan lembar kerja desain kegiatan labolatorium yang dikumpulkan peserta yang meliputi: hasil "Evaluasi Kinerja Desain dan Melakukan Eksperimen" terhadap 34 peserta yang mengikuti pelatihan diperoleh hasil rata-rata kelas sebagaimana diperlihatkan pada Tabel 1 berikut:

Tabel 1. Hasil Penilaian Kinerja Desain dan Melakukan Eksperimen

\begin{tabular}{|c|c|c|}
\hline No. & Jenis Keterampilan dan Kemampuan & $\begin{array}{l}\text { Nilai Rerata } \\
\text { Kelas }\end{array}$ \\
\hline 1. & Mengidentifikasi pola hubungan / penjelasan yang akan diuji & 3,70 \\
\hline 2. & Menggunakan pola hubungan/penjelasan untuk membuat prediksi (hipotesis) & 3,60 \\
\hline 3. & $\begin{array}{l}\text { Mengidentifikasi dan memahami makna dari setiap asumsi tambahan yang dibuat } \\
\text { dalam membuat prediksi (hipotesis) }\end{array}$ & 3,50 \\
\hline 4. & $\begin{array}{l}\text { Memutuskan apa yang diamati, dan mengidentifikasi variabel bebas dan variabel } \\
\text { terikat }\end{array}$ & 3,50 \\
\hline 5. & Menunjukkan pemahaman pengulangan percobaan & 3,85 \\
\hline 6. & Merancang eksperimen untuk mengujipola hubungan/penjelasan/ prediksi/hipotesis. & 3,35 \\
\hline 7. & $\begin{array}{l}\text { Dapat menggunakan strategi empat pertanyaan untuk menghasilkan desain } \\
\text { eksperimen }\end{array}$ & 3,85 \\
\hline 8. & Menggunakan peralatan yang tersedia untuk melakukan pengukuran & 3,70 \\
\hline 9. & Menunjukkan kemampuan merekam data dengan benar. & 3,65 \\
\hline 10. & Mendeskripsikan data hasil pengamatan dalam grafika dan atau tabel. & 3,35 \\
\hline 11. & $\begin{array}{l}\text { Memutuskan apakah prediksi (hipotesis) diterima/ditolak berdasarkan hasil-hasil } \\
\text { eksperimen }\end{array}$ & 3,50 \\
\hline 12. & Membuat rasionalisasi tentang keputusan tentang diterima/ditolaknya hipotesis & 3,40 \\
\hline 13. & $\begin{array}{l}\text { Mengidentifikasi kekurangan dalam rancangan eksperimen dan mengusulkan } \\
\text { modifikasi yang berguna }\end{array}$ & 3,10 \\
\hline 14. & $\begin{array}{l}\text { Menunjukkan pemahaman tentang cara menulis } \\
\text { panduan kegiatan lab dengan benar }\end{array}$ & 3,35 \\
\hline 15. & Melengkapi hasil eksperimen dengan metode independen. & 3,20 \\
\hline 16. & Menyelesaikan eksperimen tepat waktu. & 3,30 \\
\hline
\end{tabular}


Berdasarkan hasil penilaian Kinerja Desain dan Melakukan Eksperimendi atas tampak secara umum memperoleh rata-rata kelas untuk seluruh aspek 3,49 yang masuk dalam ketegori sangat baik. Bila dilihat pada aspek penilaian yang mendapat penilaian tertinggi 3,85 yaitu aspek nomor 5 dan 7, hal ini menunjukan bahwa seluruh peserta pelatihan dalam merancang eksperimen telah mendesain eksperimennya untuk mendapatkan data berulang/majemuk dan dalam mendesain eksperimen selalu dimulai dengan menggunakan strategi empat pertanyaan untuk menghasilkan desain eksperimen.

Pada aspek penilaian nomor 13 mendapat penilaian terendah yaitu 3,10 , hal ini menunjukan bahwa masih banyak peserta pelatihan dalam merancang eksperimen belum dapat mengidentifikasi atau mengevaluasi kembali kekurangan pada rancangan eksperimen yang terciptadan sehingga tidak dapat mengusulkan modifikasi yang berguna pada rancangan eksperimen pada materi yang sama berikutnya.

\section{Respon Peserta terhadap Kegiatan Pelatihan}

Setelah kegiatan "Pelatihan Merancang Kegiatan Laboratorium Berorentasi pada Pendekatan Saintifik bagi Guru Fisika Sidoarjo" ini seluruh peserta diminta untuk menjawab Instrumen Angket Respon Pelatihan untuk mengetahui pemahaman peserta terhadap materi pelatihan dan pendapatnya terhadap pelatihan yang dilaksanakan ini. Instrumen angket ini berisi 10 pertanyaan sebagaimana tertera pada Tabel 2.
Tabel 2. Hasil Respon Peserta Terhadap Kegiatan Pelatihan

\begin{tabular}{|c|c|c|}
\hline No. & Peryataan Angket & $\begin{array}{c}\text { Persentase } \\
\text { Tanggapan } \\
\text { Positif }\end{array}$ \\
\hline
\end{tabular}

1. Berkaitan dengan materi workshop, materi merupakan hal yang baru

2. Materi yang diberikan dapat membantu saya untuk merancang kegiatan laboratorium

3. Modul dan lembar kerja yang diberikan pada saat workshop membantu saya merancang kegiatan laboratorium secara runtut tahap demi tahap

4. Dengan workshop ini saya merasa memperoleh gambaran yang kongkrit bagaimana tahapan dalam merancang kegiatan laboratorium

5. Menurut saya,pelaksanaan Workshop ini cukup efektif

6. Menurut saya alokasi waktu workshop sangat sesuai

7. Pengetahuan/keterampilan yang saya peroleh dari kegiatan ini dapat saya manfaatkan dalam pembelajaran di kelas

8. Pelatihan ini menyediakan sumber dan media belajar yang kaya/beragam

9. Pembelajaran dari pelatihan ini memacu saya untuk ingin lebih belajar lebih dalam lagi

10. Secara umum, saya merasa puas mengikuti kegiatan pelatihan ini 100 Rata-Rata 91

Berdasarkan hasil pengisian angket yang dilakukan oleh seluruh peserta yang berjumlah 34 orang guru fisika, diperoleh persentase tanggapan positif sebagaimana terlihat pada pada Tabel 2 di atas. 
Berdasarkan pemaparan hasil angket di atas tampak dengan jelas bahwa rata-rata seluruh persentase tanggapan positif lebih besar dari $80 \%$ tepatnya 31 dari 34 peserta sehingga secara klasikal mendapat persentase tanggapan positif $91 \%$. Diantara seluruh pertanyaan angket pertanyaan nomor 6 memperoleh tanggapan positif paling kecil yaitu 28 dari 34 peserta bila dinyatakan dalam persentase $82 \%$, hal ini dikarenakan faktor lamanya waktu pelatihan sampai 3 hari dimana satu hari pada hari terakhir merupakan kerja mandiri.

Tanggapan positif maksimal $100 \%$ diberikan pada pertanyaan pada nomor 7 dan 10 hal ini menunjukkan bahwa pelatihan ini akan bisa dirasakan manfaatnya karena keterampilan mendesain kegiatan laboratorium akan dapat secara langsung diterapka pada pembelajaran di dalam kelas dan tanggapan positif maksimal pada nomor 10 menunjukkan bahwa secara umum pelaksanaan pelatihan telah dilaksanakan dengan sangat baik dan sesuai dengan kebutuhan seluruh peserta.

\section{KESIMPULAN}

\section{Kesimpulan}

Adapun kesimpulan dari kegiatan ini adalah (1) Hasil kemampuan merancang kegiatan laboratorium bagi guru guru Fisika MGMP Sidoarjo mendapatkan kategori sangat baik dengan rerata skor 3,49; dan (2) Respon guru-guru peserta pelatihan yang memberi tanggapan positif terhadap kegiatan pelatihan merancang kegiatan laboratorium sebanyak $91 \%$.

\section{Saran}

Berdasarkan hasil penelitian, saran yang dapat dilakukan untuk kegiatan berikutnya adalah (1) Kegiatan ini perlu ditindaklanjuti dengan pelatihan dalam sekala yang lebih besar yang secara mandiri bisa didanai oleh Dinas Pendidikan Sidoarjo; dan (2) Perlu dilakukan penjalinan kerja sama yang lebih kuat antara FMIPA Unesa dengan Dinas Pendidikan Sidoarjo melalui penandatanganan MoU dari kedua belah pihak, sebagai wadah dosen dan mahasiswa dalam menjalankan Tridharma Perguruan Tinggi.

\section{UCAPAN TERIMA KASIH}

Ucapan terima kasih dapat ditujukan pada

1. Kepala Lembaga Penelitian dan Pengabdian kepada Masyarakat Unesa Bapak Prof. Dr. Ir. I. Wayan Susila, M.T. yang telah mendanai dan memberikan ijin pelaksanaan workshop pelatihan ini

2. Dekan FMIPA Unesa Bapak Prof. Dr. Suyono, M.Pd., yang telah mendanai dan memberikan ijin pelaksanaan kegiatan workshop pelatihan ini.

3. Kepala Dinas Pendidikan Sidoarjo Bapak Drs. Mustain, M.Pd.I. yang telah memfasilitasi terlaksananya kegiatan workshop pelatihan ini.

\section{DAFTAR PUSTAKA}

[1] McDermott LC, Shafer PS, dan Constantinou CP. Preparing teachers to teach physics and physical science by inquiry. Phys. Educ. 2000; 35(6): 411-416. DOI: $\underline{10.1088 / 0031-9120 / 35 / 6 / 306}$

[2] Hungeford. Science-Technology- Society: Investigating and Evaluating STS Issues and Solution. Illinois: STIPES Publ; 1990.

[3] Lawson AE. Science Teaching and the Development of Thinking. California: Wadsworth Publishing Company; 1995.

[4] Yager E, Robert E. Science/Technology/ Society as Reform In Science Education. Albany: State University of New York Press; 1996.

[5] Depdiknas. Kurikulum 2004 SMA: Pedoman Khusus Pengembangan Silabus dan Penilaian Alat Pelajaran Fisika.Jakarta: Dirjen Dikdasmen Direktorat Tenaga Kependidikan; 2003.

[6] Depdiknas. Standar Kompetensi Guru 
Sekolah Lanjutan Tingkai Atas. Jakarta: Dirjen Dikdasmen Direktorat Tenaga Kependidikan; 2003.

[7] Rustad SA, Munandar, dan Dwiyanto Analisis Prasarana dan Sarana Pendidikan SD/MI, SMP/MTs dan SMA/SMK. Jakarta: Balitbang, Depdiknas; 2004.

[8] Wiyanto Pengembangan Kemam- puan Merancang Kegiatan Laboratorium Fisika Berbasis Inkuiri bagi Mahasiswa Calon Guru. Jurnal Pendidikan dan Pengajaran
IKIP Negeri Singaraja. 2006; 2.

[9] Depdikbud. http://psma.kemdikbud.go. $\mathrm{id} /$ statistik/data06a.php?lab=LABORAT ORIUM\%20Fisika (diakses pada 4 Juni 2014)

[10] Lazarowitz R dan Tamir P. "Research on Using Laboratory Instruction in Science."Handbook of Research on Science Teaching and Learning. Editor: Gabel DL. New York: Macmillan Publishing Company; 1994. 